\title{
Concepts, Tools and Methods for Crisis Management Training
}

The purpose of this chapter is to provide an overview of the field of crisis management training. As a first step, the descriptive elements of the crisis unit will make it possible to delineate the characteristics of this top decision-making place. Then, the different aspects of crisis management training will be addressed, before thoroughly introducing the concept of crisis simulations, which are one of the specific forms that trainings may adopt. Simulations are built and characterized by scenarios which materialize the training goals and educational content and thus favor a relevant organizational learning process. Finally, in order to illustrate the overview of this problem, we will portray the simulation and research platform of the French Institute of Risk Sciences (IMT Mines Alès).

\subsection{The crisis unit at the heart of the process}

The crisis team reunites decision makers who face a critical situation in a single place.

A crisis unit can be defined as a team with strong organizational integration (Sundstrom et al. 1990), in which different roles and

Chapter written by Sophie SAUVAgnargues, Dimitri LAPIERRE, Philippe Limousin, Noémie Fréalle, Florian Tena-Chollet, Pierre-Alain Ayral, Aurélia BONY-DANDRIEUX and Jérôme TIXIER. 
responsibilities are finely structured (Salas et al. 1992) and hierarchized (Ahlstrom et al. 2000; Vraie et al. 2010). The members of the crisis unit are mobilized because of their skills and knowledge, and share a frame of reference and procedures (Ahlström et al. 2000) in order to accomplish the missions entrusted to them (Lachtar 2012). Considering that the activation of a crisis unit depends on the occurrence of an event requiring its mobilization, it is actually an ephemeral organization (Dautun and Lacroix 2013; MAEE 2017).

This top decision-making place, which, by definition, must suddenly be ready for operations, can quickly assume the features of a bunker, in order to accomplish its function for centralizing the various members of the organization (Maisonneuve 2010). However, it is essential that its members do not perceive the crisis room as a bunker (Lagadec 1995, 2012), so as to avoid the harmful effects of confinement on the decision-making process.

Human behavior, whether individual or collective, is at the core of a crisis unit's life (Guzzo et al. 1995; Marks et al. 2001; Weil et al. 2004; Hussain et al. 2007). Beyond the achievement of specific tasks, behavioral processes occupy a prominent place in the functioning of the crisis unit (Shanahan et al. 2007), particularly in regard to coordination, cooperation and communication mechanisms between members. In an emergency, the decision-making process is complex because the crisis unit is exposed to high levels of stress (highly challenging decisions, hierarchical or media pressure, etc.), as well as different prejudices, which may have an impact on its members, their representations and their decisions. During the acute phase of a crisis, it seems that policymakers prefer procedural (Crichton 2000; O'Connor and Dea 2007; Lagadec 2012), intuitive (Klein 1997; Lagadec and Guilhou 2002a,b) and creative (Crichton 2000; O'Connor and Dea 2007) decision-making, in the measure that their experience and the unpredictability of the crisis increase (Lapierre 2016).

Therefore, training exercises can prepare crisis unit decision makers for the complexity of these unstable universes, and help them to deal with the obstacles encountered during a critical situation, 
regardless of whether these are individual difficulties or collective dysfunctions.

Collective dysfunctions mainly concern the transmission of information within the crisis unit, as well as among the actors involved, particularly on how they understand the situation and cope with stress and organizational aspects. They have a direct impact on decision-making and an indirect one on the whole of the organization. These dysfunctions can be classified according to the categories presented in Table 1.1.

\begin{tabular}{|c|c|}
\hline $\begin{array}{l}\text { Problems related to the transmission of } \\
\text { information }\end{array}$ & References \\
\hline Weak information sharing & King et al. (2008) \\
\hline $\begin{array}{l}\text { Improper information transmission: } \\
\text { omissions, inaccuracies, lack of clarity, etc. }\end{array}$ & $\begin{array}{l}\text { Crichton and Flin (2004), } \\
\text { Guarnieri et al. (2016), Guarnier } \\
\text { et al. }(2015)\end{array}$ \\
\hline $\begin{array}{l}\text { Selectivity in the information chosen, } \\
\text { oversight of other relevant data }\end{array}$ & $\begin{array}{l}\text { Kowalski-Trakofler and Vaught } \\
\text { (2003), Guarnieri et al. (2015) }\end{array}$ \\
\hline Lack of validation, decision control & Guarnieri et al. (2015) \\
\hline \multicolumn{2}{|l|}{ Dysfunctions related to the situation } \\
\hline $\begin{array}{l}\text { Insufficient knowledge about the event and } \\
\text { the stakes involved }\end{array}$ & Dautun (2007) \\
\hline $\begin{array}{l}\text { Difficulty to obtain a common operating } \\
\text { picture, a common mental representation }\end{array}$ & $\begin{array}{l}\text { Seppänen et al. (2013), Lagadec } \\
\text { (2015) }\end{array}$ \\
\hline Collapse of sense ("sense-making") & Weick (1995) \\
\hline Control fantasy & Kouabenan et al. (2006) \\
\hline $\begin{array}{l}\text { Misrepresentation of risk, normalization of } \\
\text { deviance }\end{array}$ & Vaughan (1996) \\
\hline Effects of "groupthink" on the crisis unit & Guarnieri et al. (2015) \\
\hline Lack of perspective on the situation & Lagadec and Guilhou (2002a,b) \\
\hline Negation of the unexpected & Lagadec (2012) \\
\hline $\begin{array}{l}\text { Inadequate or erroneous assessment of the } \\
\text { situation }\end{array}$ & $\begin{array}{l}\text { Crichton and Flin (2004), } \\
\text { Guarnieri et al. (2015), Orasanu } \\
(2010)\end{array}$ \\
\hline
\end{tabular}




\begin{tabular}{|c|c|}
\hline $\begin{array}{l}\text { Misunderstanding in the face of } \\
\text { inconsistent, inadequate or unfeasible } \\
\text { demands }\end{array}$ & Guarnieri et al. (2015) \\
\hline \multicolumn{2}{|l|}{ Dysfunctions related to stress } \\
\hline $\begin{array}{l}\text { Denial, voluntary blindness, negation of the } \\
\text { unexpected }\end{array}$ & $\begin{array}{l}\text { Kouabenan et al. (2006), Lagadec } \\
\text { (2010), Heiderich (2010), } \\
\text { Lagadec (2012) }\end{array}$ \\
\hline $\begin{array}{l}\text { Blocking action, ineffective processing of } \\
\text { information }\end{array}$ & $\begin{array}{l}\text { Kouabenan et al. (2006), } \\
\text { Combalbert and Delbecque } \\
(2012)\end{array}$ \\
\hline Feeling of invulnerability & Kouabenan et al. (2006) \\
\hline Consternation & Crocq et al. (2009) \\
\hline Disorientation of members & Heiderich (2010) \\
\hline \begin{tabular}{|l}
$\begin{array}{l}\text { Decrease in alertness and memory } \\
\text { capabilities }\end{array}$ \\
\end{tabular} & $\begin{array}{l}\text { Kontogiannis and Kossiavelou } \\
(1999)\end{array}$ \\
\hline $\begin{array}{l}\text { Need to find/appoint leaders, instead of } \\
\text { becoming involved }\end{array}$ & Wybo (2009) \\
\hline $\begin{array}{l}\text { Ignorance, beliefs, ideology, arrogance and } \\
\text { intellectual misrepresentation }\end{array}$ & $\begin{array}{l}\text { Lagadec (2010), Heiderich } \\
\text { (2010), Lagadec (2012) }\end{array}$ \\
\hline \multicolumn{2}{|l|}{ Organizational dysfunctions } \\
\hline $\begin{array}{l}\text { Partial implementation or difficulty of } \\
\text { setting up the cell }\end{array}$ & Dautun (2007) \\
\hline Lack of available resources & Guarnieri et al. (2015) \\
\hline Lack of reflexes, or bad reflexes & Suchet (2015) \\
\hline Ambiguity of roles & Moulin (2014) \\
\hline $\begin{array}{l}\text { Incorrect distribution of tasks, lack of (or } \\
\text { bad pooling of) resources }\end{array}$ & Kanki (2010) \\
\hline $\begin{array}{l}\text { Blind endorsement or misapplication of } \\
\text { procedures }\end{array}$ & $\begin{array}{l}\text { Crichton and Flin (2004), } \\
\text { Lagadec (2012) }\end{array}$ \\
\hline Weak leadership & Kanki (2010), Moulin (2014) \\
\hline Disobedience to the leader & Guarnieri et al. (2015) \\
\hline Tensions, conflicts, lack of cohesion & $\begin{array}{l}\text { Van Vliet and van Amelsfoort } \\
\text { (2008), Argillos (2004) }\end{array}$ \\
\hline Lack of consensus & Denis (1993) \\
\hline
\end{tabular}




\begin{tabular}{|l|l|}
\hline Collapse or lack of coordination devices & $\begin{array}{l}\text { Weick (1995), Lagadec (2012), } \\
\text { Kim et al. (2015), Smith and } \\
\text { Dowell (2000) }\end{array}$ \\
\hline $\begin{array}{l}\text { Lack of support from the leaders, excessive } \\
\text { hierarchical pressure }\end{array}$ & Guarnieri et al. (2015) \\
\hline $\begin{array}{l}\text { Lack of deep personal knowledge and of } \\
\text { other players }\end{array}$ & Moulin (2014) \\
\hline $\begin{array}{l}\text { Isolation and confinement of crisis unit } \\
\text { members }\end{array}$ & Guarnieri et al. (2015) \\
\hline $\begin{array}{l}\text { Lack of adaptability, difficulty to innovate, } \\
\text { improvise or reorganize oneself }\end{array}$ & $\begin{array}{l}\text { Edmond (2011), Autissier et al. } \\
\text { (2012) }\end{array}$ \\
\hline Lack of anticipation & Lagadec and Guilhou (2002a,b) \\
\hline $\begin{array}{l}\text { Dysfunctions associated with external } \\
\text { crisis communication }\end{array}$ & \\
\hline $\begin{array}{l}\text { Absence or lack of external communication } \\
\text { to the cell }\end{array}$ & Lagadec (1995) \\
\hline $\begin{array}{l}\text { Difficult or inappropriate communication } \\
\text { with the outside }\end{array}$ & Dautun (2007); Kim et al. (2015) \\
\hline
\end{tabular}

Table 1.1. Collective dysfunctions that may emerge at the crisis unit (according to Lapierre (2016) and Limousin (2017))

These difficulties and shortcomings show the importance of the human factor for crisis management. On the other hand, during critical situations, managers are confronted with other complications such as the lack of technical or human resources (Lagadec 2010, Guarnieri et al. 2016), incompleteness, the lack of updates and the inadequacy of emergency plans to face the situation (Dautun 2007; Cesta et al. 2014).

All of these elements have a hindering effect on the adequate management of a critical situation. Hence, there is a need for upstream training in order to avoid them, or at least to reduce their potential consequences. 


\subsection{Training for crisis units}

In order to prepare the crisis tool and make it efficient, it is necessary to raise awareness about it, test it out and constantly improve it (Solucom 2014).

Training sessions in the field of major risk and crisis management are essential for the actors involved in the crisis. Training comprises all of the theoretical lessons (learning) and drills (practicing) that make it possible to prepare oneself and to perfect one's skills (Quinton 2007). Training also contributes to increasing the readiness level of managers and highlights the functional, technical and organizational problems inherent in crisis management (Renaudin and Altemaire 2007).

Training sessions may cover several objectives, in particular to:

-test documentation, plans, procedures and the operational capability of crisis management tools (Gaultier et al. 2012);

-highlight dysfunctions and the areas to be improved (Heiderich 2010);

-encourage the crisis members to gain experience (Sayegh et al. 2004; Tissigton and Flin 2005); 2012);

-test the efficiency of mobilized staff (Gaultier-Gaillard et al.

-raise the level of expertise of the actors involved (Crichton 2001).

The skills that should be developed by managers are manifold. On another note, the dysfunctions previously identified in the crisis units highlight the need to insist on several criteria during the training sessions:

-Reflection in the middle of an emergency: an emergency is typical during the acute phase of a crisis; therefore, it must be integrated in training scenarios. It is necessary to generate stressful situations within the frame of exercise scenarios in view of imposing quick thinking to decision makers while destabilizing their organization. 
-Group: training should focus on the reactions and behavior of the group as a whole, and not on individuals, relying on the fundamental skills of the trained group (decision-making, communication, situational awareness, leadership, coordination).

-Objectives: group learning should be at the heart of the approach. Promoting exercises in strenuous conditions also contributes to the characterization of individual and collective goals throughout the training.

-Learning the surprise element and anticipating disruption (Roux-Dufort and Ramboatiana 2006).

At present, there are many types of trainings, which may vary strongly (Bapst and Gaspar 2011). Stern and Hedstrom have tried to find consensus as regards training terminology (Stern 2014). The first distinction is the fact that training can be theoretical or practical. The second one focuses on the difference between courses for developing skills and those which help members to put these skills into action.

On another note, it is possible to distinguish between education, functional exercise, training and courses:

-Education is defined as a training program designed to increase the knowledge or understanding of a topic. Education is opposite to training for improving skills related to a specific task (Department of Homeland Security FEMA, 2015).

-A functional exercise is a commonly practiced activity in order to test a single and specific operation or the function of an entity (Blanchard 2008).

-Training is a coordinated and supervised action which is usually performed in view of validating an operation or a specific function within an organization. Training is performed in order to become used to new equipment, to develop or test new procedures or to maintain acquired skills (Department of Homeland Security of FEMA 2005).

-Courses correspond to activities which have been scheduled in order to improve the effectiveness of individuals and organizations (Blanchard 2008). 
A classification has been proposed by the HSEEP (Homeland Security Exercise and Evaluation Program) for the totality of crisis management trainings. These are classified according to the required skills, necessary preparation and upstream training (Lee et al. 2006) so as to reach different educational levels:

- The seminar helps trainees to obtain a general overview of crisis management. For this purpose, authorities, strategies, plans and regulations can be introduced. Besides, seminars are a good tool to raise awareness about crisis management (Department of Homeland Security of FEMA 2013).

-If the goals are initially well defined, then workshops can favor the achievement of a concrete result (procedure, protocol, concept). It is appropriate to propose workshops to crisis management actors, because this enables them to later include what has been produced by their work (Department of Homeland Security of FEMA 2013).

-Tabletop exercises are intended to spark discussions regarding a simulated emergency within a caring framework. If trainees become engaged in these exercises, awareness and the understanding of concepts and/or procedures are effective (Tena-Chollet 2012; Department of Homeland Security of FEMA 2013).

-Games are simulations of operations which enable trainees to explore plans or processes. The format of the game and its rules is open, in order to experience some aspects in real time or to linger on the decision-making process (Department of Homeland Security of FEMA 2013). Games also help participants to explore the decision-making processes resulting from plans, by exploring their consequences (Renger et al. 2009).

-Practical exercises are tests in which only one operation or function is evaluated. Exercises are simulated in real time and can last 2 to 4 hours (Federal Emergency Management Agency 2008).

-Functional exercises are conducted in real time and in the usual crisis management environment (Tena-Chollet 2012; Department of Homeland Security of FEMA 2013). They do not address all of the functions of crisis management and limit the movements of staff and 
equipment, which are consequently simulated (Tena-Chollet 2012; Department of Homeland Security of FEMA 2013).

-Large-scale exercises can be considered as the most ambitious ones (DDSC 2005), in virtue of their complex preparation and the significant resources they require in order to reliably reproduce an event (Department of Homeland Security of FEMA 2013). They involve a large number of stakeholders who can identify problems (including cooperation among different departments) and then adjust the procedures that must be followed (Tena-Chollet 2012; Department of Homeland Security of FEMA 2013).

We can complete this classification with serious games, defined as "a computer application, whose initial intention is to consistently combine serious aspects, such as education, learning, communication, or information, with playful proposals derived from video games (games). Such an association can take place thanks to the implementation of a 'utility scenario', that is to say, a special presentation (with sounds and graphs), including a script as well as appropriate rules, whose intention from the very beginning is to go beyond simple entertainment" (Alvarez 2007). Serious games can be classified into three categories (Lhuillier 2011):

-Learning games are serious games for learning or training, with the main goal of providing training to enhance the acquisition of skills and knowledge.

-Persuasive games are used for communicating informative, persuasive (institutional communication, advertising, etc.) or subjective (propaganda) messages. Their goals are to seduce, promote, influence and persuade.

-Simulations are used for training players in the acquisition of reflexes. Thus, the trainee can repeat and reproduce certain gestures or procedures and perfect them.

The training offer is rich, as shown in Figure 1.1 (Fréalle 2018). It is also important to choose training activities in a consistent manner, that is, in harmony with the educational goals and the predetermined training scenario. It is also essential for the trainer to adapt to trainees, in order to improve the quality of the learning experience 
(Bristow et al. 2011). Finally, training in crisis management should be an immersive experience based on real events, and truthfully reflect the discussion on the causes, consequences, prevention and management of crises (Shrivastava et al. 2012).

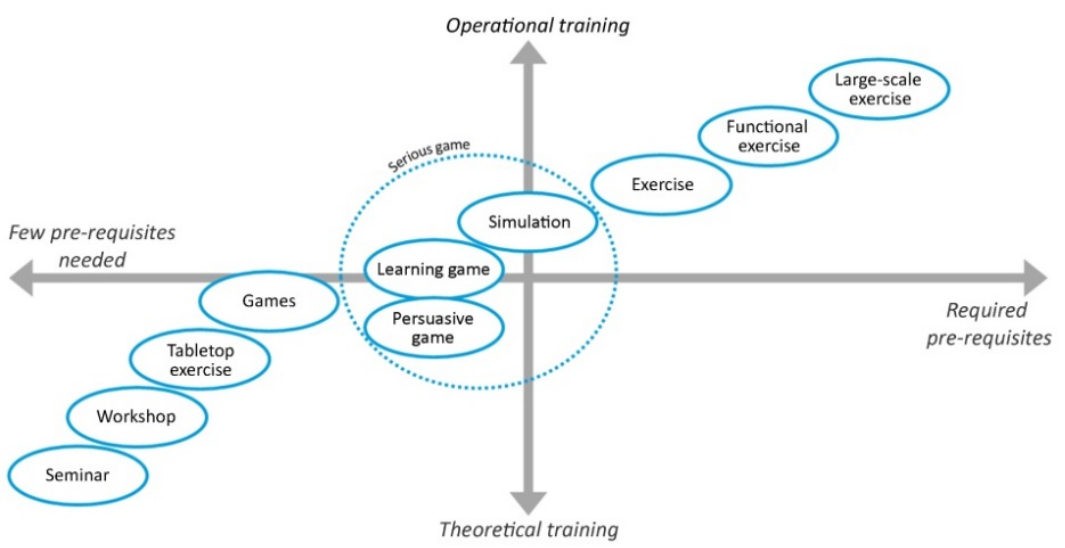

Figure 1.1. A summary of the different types of training that can be used for crisis management training (Fréalle 2018). For a color version of this figure, see www.iste.co.uk/sauvagnargues/crisis.zip

\subsection{Simulation of critical situations}

Here, attention is focused on successful simulations so that trainees can integrate knowledge (Miles et al. 1986 and Jennings 2002 in Goebel and Humphreys 2014). Simulation allows trainees to simulate reality and acquire a type of experience which may be perceived as a rite of passage (Goutx 2014). It is necessary to make sure that the training, and most importantly the simulation, will help organizers reach educational goals and thus improve organizational resiliency.

The use of simulation is becoming increasingly widespread in the learning process (Pernin 1996; Mellet d'Huart 2001; Pastré 2005). The main practical reasons underlying the interest in the use of simulation have been studied by many authors (Crichton et al. 2000; Banks 2001; Lourdeaux 2001; Borodzicz et al. 2002; Querrec 2002; Guéraud 2003; Kincaid et al. 2003; Guéraud 2005; Bruinsma and De Hoog 2006; Idasiak et al. 2006; Joab et al. 2006; Mendonca et al. 2006; 
Schurr et al. 2006; Crichton 2009). The interest of simulation can be defined through:

-the potential danger to humans, the environment or the equipment when working on the real system (risky or situations difficult to reproduce);

-the source of anxiety that the real system may represent for a beginner;

-the ability to simulate extremely severe situations to prepare the trainee to respond to them;

-the freedom from the constraint of a time scale which may ease understanding;

-the opportunity to simplify or alter a reality in order to study it better;

-the acquisition of skills related to decision-making and problem-solving;

-the interest for the trainee; since simulation can act as a source of motivation, it can contribute to a better understanding of phenomena and a greater ability to become adapted in similar situations;

-training costs which are lower, regardless of whether they are related to financial issues or problems concerning the mobilization of staff.

By definition, a simulator is "a dynamic technical and human environment, endowed with interactive points which the operator may manipulate in order to cause, observe or control changes in this environment" (Crampes and Saussac 1999). The purpose of this type of tool is to learn technical and non-technical skills, know-how and reflective practices. For this purpose, a simulator is supposed to integrate parameters such as realism, time and the stakes involved, in order to favor the complete immersion of the participant. The temporal component can be divided into two categories: real time for simulations taking place within the same temporal space as the real and simulated time, which corresponds to an acceleration or 
deceleration in real time (Crampes and Saussac 1998). Pernin identifies three contexts in which simulations are used (Pernin 1996):

-the traditional context in which the pedagogue resorts to simulation for demonstrative purposes, or suggests activities related to simulation. His role is to guide and help trainees;

-an independent use, as part of self-training or self-assessment;

-cooperative use in the context of a group of trainees doing cooperative work based on simulation.

We should observe that the use of simulators is spreading in different contexts and training frameworks. Various works tend to explain their effectiveness in learning through fixed educational goals, a set of rules particularly defined for the trainee and the guidance offered by facilitators (Pernin 1996; Cortes Buitrago 1999). In this way, in educational simulators, the trainee is placed in a learning situation through discovery and action (Pernin 1996; Joab et al. 2006; Labat et al. 2006). The main intention for using educational simulation is to favor the learning process, which is not necessarily related to the accuracy of the modeling of the simulated system (Cortes Buitrago 1999; Crampes and Saussac 1999; Joab et al. 2006). Hence, a pedagogical simulation designer is free to simplify or highlight specific phenomena or some features of the simulated system when these differences are justified from a pedagogical point of view. Exercises are usually supervised by one or more trainers (Joab et al. 2006), and didactic interventions must be defined according to several criteria. In fact, each event scenario depends on the profile of the trainee and the type of error he tends to make (Lourdeaux 2001). In general, the more the trained individual is confirmed, the better it is to make him aware of his mistake, without taking him out of the simulated situation.

In the design of a simulator for educational purposes, it is important to define the different teaching strategies from the beginning. These may include the following elements: the motivation process (stakes, competition, emergency, etc.), a performance evaluation, the way in which knowledge will be brought forward and, finally, the way in which the trainee will acquire experience. Realism 
is an important element, but it has nonetheless been proven that it should leave room for imagination so that trainees can take ownership of the situation (Crampes and Saussac 1999). According to the proposed training and the goal set, participants can play one or many different roles during the same training.

Visualization is also one of the key elements involved in simulation, given the fact that since childhood, the human brain has been used to primarily focus on the visual aspect of things (Rohrer 2000). In order to improve the process of human understanding, different sources of information can be made accessible and should be chosen on the basis of the message that must be conveyed (Morin et al. 2004):

-visual aims, which can be adapted so that teams can feel motivated;

-maps, which can be dedicated to monitoring of the situation and illustrating the geographical limits of the simulation territory;

-statistics, which can enable the synthesis of a large amount of data;

-temporal trends, which can foster the perception of changes in the simulated system;

-photographs, which can statically illustrate a situation;

$-2 \mathrm{D}$ or $3 \mathrm{D}$ animations, which can properly reflect the dynamics of events.

The benefits associated with the use of simulation for educational purposes are manifold (Banks 2000). First, it is possible to test the simulation parameters and validate them (or not). It is also possible to understand why an event takes place in one way or another, by studying it in retrospect and exploring different evolutions of the simulated scenario, in order to learn from previous mistakes without risking real-life consequences (Mendonca et al. 2006).

However, simulation also presents some drawbacks related to the difficulty of representing results (transcription problem) and the assessment of team performance (interpretation problem). This stems 
from the fact that the impact of decisions made by the group regarding the evolution of simulation is not often observable or is difficult to measure (Banks 2000).

It is therefore necessary to reflect upon the strategies that must be integrated so as to improve the collective learning of participants. For this purpose, different levers should be considered, such as a better characterization of needs and expectations from trainees, and a better appraisal of the non-technical skills of a group, associated with the enrichment of learning environments.

\subsection{The construction of crisis simulation exercises}

A better consideration of non-technical skills initially requires a precise identification of the training exercise goals (Salas and Cannon-Bowers 2001; Bernard 2014). An analysis of the tasks (or actions) that must be achieved needs to be conducted before the exercise; that is, it should characterize the expectations related to scheduled tasks. A cognitive task analysis can be performed by the designers of the training. Before the exercise, this technique explores the skills that will be needed by trainees in order to perform the task (abilities, association of ideas, existing rules or procedures). This will allow educators to improve the design of scenarios, by incorporating more of the trainees' needs. On the other hand, once these various elements have been identified, the technique makes it possible to easily translate such needs into learning objectives and later transcribe them within the scenario construction phase.

In fact, when a crisis occurs, non-technical skills, and specifically psycho-social factors, are generally lacking. The crisis takes place under psychological strain, whether at the individual or collective level, because the time of the crisis is an accelerated time, rushed, in which things are going too fast in the minds of the individuals (Crocq et al. 2009). Individuals who experience the crisis think that they are no longer able to control events as the situation goes far beyond their reach. They are obliged to suddenly change their habits and undergo a sole life-saving imperative, to effectively make a decision in a very 
short time lapse. The preparation of decision makers through training rarely meets these criteria (Pearson and Clair 1998).

Fear, anxiety, anguish and stress, which have an impact on decision-making, modify the group dynamics and the representation of the situation (Heiderich 2010), which are all examples of appropriate or inappropriate reactions on the part of managers in the middle of the emergency (Crocq 2007; Dautun 2007). However, during training, it is very difficult to inject the stimuli of fear, anxiety or stress due to the exercise context. NASA designs exercises in which the fatigue factor is predominant, in order to evaluate the decision-making abilities of staff. This type of training is rare in other areas (Helmreich et al. 1986).

In order to increase the recognition of these aspects, several authors have suggested that more emphasis should be placed on transmitting the informal rules which are at work during critical situations to decision makers and operators (Llory 1996). Recommendations or simple practical rules can be proposed to train decision makers during the course: among these recommendations, some can be mentioned, particularly in view of strengthening the enforcement of procedures and of reducing associated errors which often occur when hasty decisions are made. For example, in case of doubt, it is recommended to double-check information. This principle also applies when the different stages of a procedure must be respected. It should be emphasized that some of these should not be forgotten, even in the context of a crisis (Llory 1996).

Finally, other authors have emphasized the importance of some skills that are essential for all organizations, but often overlooked (Lagadec 2012): for a long time, exercises have focused on procedures to be applied, instead of the human or organizational factor. The same applies to oral communication: specific learning activities should focus on some particular skills (Seppänen et al. 2013), such as making people speak one after the other, generating actions that can only be achieved with the joint efforts of many or working on the type of information exchanged. Training participants on how to communicate among members in unfavorable conditions (Quarantelli 1988), 
simulating media pressure, varying the different channels for disseminating information (Becerra et al. 2013) or considering the impact of social networks in managing emergencies (particularly, Social Media in Emergency Management - SMEM) are part of these recommendations (Martin 2014).

In addition to the major dysfunctions that a crisis unit may have to meet, the importance of the working habits of decision makers, as well as their initial thinking environment, should also be reconsidered.

Organizational learning takes place by activating levers at different moments within a training schedule, all the more considering that improvement is possible at all levels: in the context of a (real or simulated) crisis, an emergency deprives decision makers from deep knowledge of the situation and thus becomes one of the first areas to be improved. It is therefore necessary to educate trainees to embark upon an information-sharing process.

The elements regarding the development of a shared awareness on the situation should be strengthened during the training exercise. In fact, shared mental models shape a common understanding of the situation among the group members, a comprehension that is essential during a critical situation. Without a common operational picture and knowledge of the roles and missions of each participant, shared awareness of the situation may be low in the crisis unit, which can have a negative impact on the decision-making process (Seppänen et al. 2013).

Operational mapping is a major component of a shared awareness of the critical situation. It helps to (graphically and dynamically) outline important shared information concerning the crisis, as well as to secure and optimize the collection, transmission and understanding of operational information at different commanding levels (Sauvagnargues and Poppi 2012).

On the other hand, four team-working processes are at the heart of such a construction to overcome collective failure (Dautun and Lacroix 2013): 
-Interpersonal communication: reformulating common terms, encouraging strong interaction between members, favoring an effective flow of information. In other words, raising awareness about closed-loop communication (Henriksen et al. 2008).

-Coordination: gathering and assembling evidence to shape a shared vision through the drafting of action, carrying out regular check-ups.

-Cooperation: mutual trust among members implies strong cooperation.

-Use of shared tools: when deprived of a vision of reality, members must create a mental image of the crisis. Therefore, this requires a high level of assistance for sharing information and effectively managing the situation. Some examples of supporting media are mapping, tracking charts and records (Lagadec 2012; Lachtar 2012).

In other words, in order to improve the quality of the learning environment, and from a material point of view, it is necessary for the places destined for training to be equipped with tools to enable trainees to share information with the whole group. The goal is to transform this approach into a reflex and to enable the group members to develop a habit.

The enrichment of the environment lies at the heart of developing a training exercise in order to create an optimal learning atmosphere: trainees should be placed in a situation that highlights their experience through "target" events, as well as expected actions and behaviors. Scenarios must be finely scripted, without nonetheless becoming rigid, which might endanger their flexibility during training (Boin et al. 2004). In one scenario, an event is never trivial, and goals, missions, actions or expectations need to be deduced beforehand (Shapiro et al. 2008).

Scenarios should ideally be based on the objectives, particularly on clearly identified educational goals, a realistic story, missions to be attained, distinct roles, specific operations and varied resources (Schank et al. 1992). When a scenario is well structured and trainees 
feel immersed in it, their motivation is positively impacted. This immersion is directly related to the environment and the exercise scenario. Many authors have pointed out that in order to favor involvement, an exercise should imperatively respect the accuracy triangle (Rehmann et al. 1995; Powers et al. 2013):

-physical aspect of the simulator: true to life equipment;

-environmental aspect of the simulator: derelict environment;

-feeling of immersion among trainees.

In order to enhance organizational learning, through the different scenarios, it is therefore convenient to elicit several distinct skills, alternate them, make changes and fluctuate the level of difficulty during the exercise (Salas and Cannon-Bowers 2001), involving a variety of institutional actors and State services related to civil security (Lagadec and Guilhou 2002b; Lagadec 2012), especially considering elements which are not spontaneously given.

The heart of a simulation is its scenario (Nissen 2009; Hotte 2016). It is necessary to understand the scriptwriting mechanics employed, so as to evaluate whether the scenario favors the achievement of educational ambitions related to learning.

The scenario of crisis management training is the story of how the future could develop (Heinzen 1995; Carroll 2000; Noori et al. 2017). The scenario designed for a simulation describes a single event or a hypothetical situation in a relatively short time frame, ranging from a few hours to a few days (Heinzen 1995). It is the tool that provides the participant with the necessary training experience so as to develop effectiveness during critical situations, by creating a feeling of flow (Csikszentmihalyi 1991) and immersion (Heinzen 1995; Lukosch et al. 2012).

Apart from being stimulating (Noori et al. 2017), the scenario should faithfully reflect reality so that learning is relevant (Dautun et al. 2011; Pastré and Vergnaud 2011), flexible and dynamic (Dautun et al. 2011; Noori et al. 2017). These characteristics can be structured through three prerequisites: the scenario must be credible, educational 
and interactive. A true-to-life scenario will be a credible scenario; a scenario favoring the acquisition or consolidation of knowledge, skills and know-how will be a pedagogical scenario; a scenario enriched with interactivity will be a flexible and dynamic scenario. To be sure that the simulation is carried out in coherence with the prerequisites, the scripting stage should take these characteristics into account.

\subsection{The simulation and research platform of the Institute of Risk Sciences (IMT Mines Alès)}

The simulation platform was built in 2011. It is a research platform in which it is possible to develop and test different devices, to immerse trainees in crisis situations, isolating them in a room representing a crisis unit. The simulation platform is composed of four rooms, which are distributed as follows (Figure 1.2):

-two rooms for trainees. It is therefore possible to separate trainees into two groups and to develop the same scenario in parallel. We can also consider forming two different crisis units and implementing a self-powered scenario;

-a room for facilitators, which is located in the heart of the simulation platform;

-the technical platform of the simulation room.

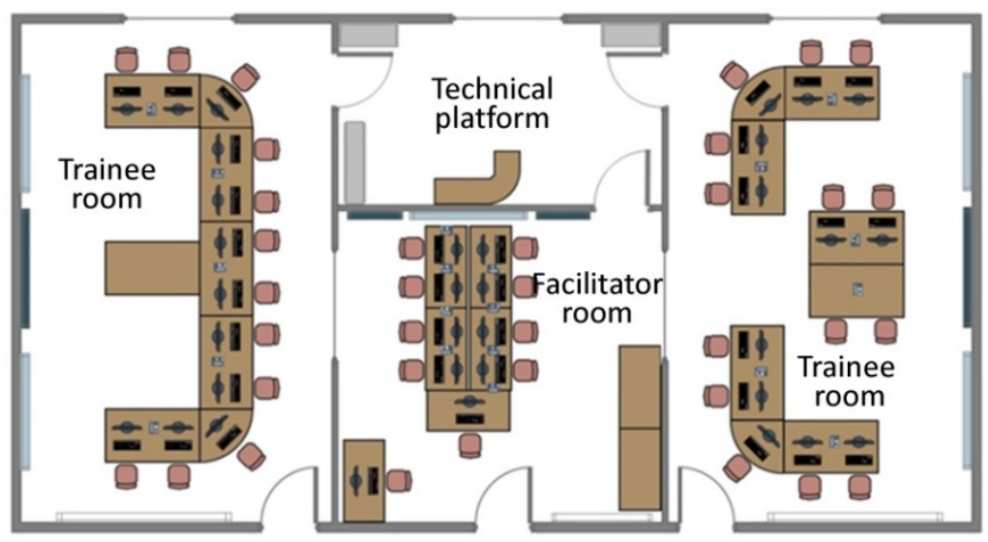

Figure 1.2. A diagram of the simulation platform. For a color version of this figure, see www.iste.co.uk/sauvagnargues/crisis.zip 
We can classify the facilities of this platform into three categories:

-The equipment available to trainees. These are facilities found in crisis units, and if they are crisis managers, they enable trainees to be placed in conditions similar to the ones that their organization may face. This may contribute to helping trainees become familiar with equipment which may not be readily available in their structure of origin. Rooms for trainees are equipped with an interactive whiteboard (IWB), a wall screen, a large touch screen, a flip chart, a whiteboard, billboards, a printer, a computer station and one phone per person.

-All this equipment enables educators to control the simulation. Thus, trainees can have access to surveillance cameras, a remote control of the trainees' screens (IWB, screen wall, touch screen), control of the trainee room's sound system, a printer, a computer station and one phone per person, an IWB, a whiteboard and billboards. One-way windows between rooms where trainees are located and the animation room enable facilitators to have direct visual access to trainees.

-Sound, visual and thermal immersion equipment for trainees. This equipment facilitates the engagement of trainees in the learning situation: obscuring shutters make it possible to avoid what is happening outside (which might discredit the simulation), the room's thermostat can be regulated and thanks to the sound system, it is possible to submit relevant sound elements related to the simulated situation to trainees.

This experimentation platform helps to control simulation settings at the best possible level. In fact, it is possible to choose the devices made available to trainees and facilitators as well as to determine the spatial organization of the crisis unit. In the way it has been introduced here, the simulator offers two configurations, a reflection of the majority of documented crisis units:

-"U-shaped" configuration: this facilitates coordination between the different poles, the transmission of information and the 
visibility of points of interest (whiteboard, flipchart, records, mapping, etc.).

-Island configuration: this facilitates work in small groups and movement of the members in the crisis unit, a feature that improves access to shared media (white tables, paperboard, records, mapping, etc.).

Implemented simulations make it possible to prepare trainees for participation in a crisis unit, by exposing them to the various obstacles and difficulties that may be encountered in these uncertain contexts. Dysfunctions, essentially collective ones, highlighted in crisis units (and described in section 1.1), are considered as reflection matter for the construction of scenarios.

Each simulation training session is subjected to the precise definition of educational goals, specially adapted to the training audience (institutional, local authorities, industrial, students). Trainings sessions are intended to promote reflection in the middle of an emergency and to provoke reactions and group behavior for decision-making, coordination, representation and shaping the collective consciousness of the situation, leadership, etc.

After the precise definition of educational objectives, each scenario is "tailor-made" for each group of trainees, whether in terms of:

-the considered triggering phenomenon (flooding, accident during the transport of hazardous materials, forest fires, hurricanes, etc.);

-the type of crisis unit deployed (communal, industrial, prefectural, civil security crisis unit);

-the implemented contingency plan (SIP, CSP, IOP, etc.);

-the overall complexity level expected from the simulation.

In addition, this simulation training platform is a support medium for research and experimentation on themes related to the development of a semi-virtual environment with multi-agent simulation (Tena-Chollet 2012), the optimized scripting of exercises 
(Limousin 2017; Fréalle 2018), the assessment of performances and aid for the construction of debriefing (Lapierre 2016) and the activation of playful resources during simulation for increasing educational impact (Goutx 2017). These multidisciplinary and integrating themes are also promoters of joint research with industrial partners (as, for example, in the nuclear field) and of collaborative projects with public funding (ANR-2014 SPICy; https://www. YouTube.com/watch?v=OcaAg_zaSdk).

What is more, this platform facilitates the implementation of simulations useful for testing new tools or approaches, whether they are technological, organizational or experimental ones.

\subsection{Conclusion}

The crisis unit is a complex study and research object. Crisis management systems and organizations are clearly identified, and yet, responses structured in this way to face a crisis are not effective enough. Preparation and crisis management training have become essential components, which can help participants to better address emergency situations or critical events.

The optimal preparation for crisis management is complex to learn, especially for trainees who are not crisis professionals (e.g. security or civil defense services), but who may nonetheless have to face a crisis. In order to meet this need, the law requires or encourages actors to carry out exercises. Crisis management training may adopt different aspects and should be adjusted to the knowledge and skills of trainees. Therefore, it appears that crisis management simulation is the best compromise to provide training for crisis management at a rather strategic level.

Social concern and expectations are important for this topic, which are reflected by abundant research, as will be shown in the following chapters. 


\subsection{References}

Ahlstrom, V., Koros, A., and Heiney, M. (2000). Team Processes in Airway Facilities Operations Control Centers. National Technical Information Service, Springfield, VA.

Alvarez, J. (2007). Du jeu vidéo au serious game : approches culturelle, pragmatique et formelle. PhD Thesis, Toulouse 2.

Argillos (2004). Esquisse d'un Alphabet de la Surprise. Argillos.

Autissier, D., Bensebaa, F., and Boudier, F. (2012). L'atlas du management. Eyrolles, Paris.

Banks, J. (2000). Introduction to simulation. 2000 Winter Simulation Conference, 10-13 December 2000, Orlando, FL, pp. 9-16.

Banks, J. (2001). Panel session: education for simulation practice - five perspectives, 2001 Winter Simulation Conference, 9-12 December 2001, Arlington, VA.

Bapst, C. and Gaspar, P. (2011). L'Europe de la formation. In Traité des sciences et des techniques de la Formation, Carré, P. and Gaspar, P. (eds). Dunod, Paris.

Becerra, S., Perltier, A., Antoine, J. M., Labat, D., Chorda, J., Ribolzi, O., Daupras, F., and Dartus, D. (2013). Comprendre les comportements face à un risque d'inondation modéré. Etude de cas dans le périurbain toulousain (Sud-Ouest de la France). Hydrol. Sci. J., 58(5), 945-965.

Bernard, L. (2014). Guide pratique de formation par la simulation. VA Presse, Paris.

Blanchard, B.W. (2008). Guide to emergency management and related terms, definitions, concepts, acronyms, organization, programs, guidance, executive orders and legislation: a tutorial on emergency management, broadly defined, past and present. Lexicon, US Federal Emergency Management Agency (FEMA), Emmitsburg.

Boin, A. (2004). Crisis Simulations: Exploring Tomorrow's Vulnerabilities and Threats. Simul. Gaming, 35(3), 378-393. http://doi.org/10.1177/ 1046878104266220.

Borodzicz, E.P. and Van Haperen, K. (2002). Individual and group learning in crisis simulations. J. Contingencies Crisis Manag., 10(3), 139-147, 2002. 
Bouglet, T. (2002). Incertitude et environnement : Essai de représentation et analyse des choix publics. PhD Thesis, University Panthéon-SorbonneParis I and U.F.R Sciences économiques.

Bristow, D., Shepherd, C.D., Humphreys, M., and Ziebell, M. (2011). To Be Or Not To Be: That Isn't the Question! An Empirical Look at Online Versus Traditional Brick-and-Mortar Courses at the University Level. Marketing Edu. Rev., 21(3), 241-250.

Bruinsma, G. and De Hoog, R. (2006). Exploring protocols for multidisciplinary disaster response using adaptive workflow simulation. 3rd International ISCRAM Conference, 14-17 May, Newark.

Carroll, J.M. (2000). Five reasons for scenario-based design. Interact. Comput., 13(1), 43-60. doi:10.1016/S0953-5438(00)00023-0.

Cesta, A., Cortellessa, G., and De Benedictis, R. (2014). Training for crisis decision making - An approach based on plan adaptation. Knowl. Based Syst., 58, 98-112.

Combalbert, L. and Delbecque, E. (2012). La gestion de crise. PUF, Paris.

Cortes Buitrago, G. (1999). Simulations et Contrôle Pédagogique : Architectures Logicielles Réutilisables. PhD Thesis, Joseph Fourier University, Grenoble.

Crampes, M. and Saussac, G. (1998). L'acte d'apprentissage au cœur de la simulation. Colloque international NTICF (Nouvelles Technologies de l'Information et de la Communication dans les Formations d'Ingénieurs et dans l'Industrie), 18-20 November, INSA, Rouen.

Crampes, M. and Saussac, G. (1999). Facteurs de qualité et composantes de scénario pour la conception de simulateurs pédagogiques à vocation comportementale. Sci. Tech. Édu., 6(1), 11-36.

Crichton, M.T. (2001). Training for decision making during emergencies. Horizons of Psychol., 10(4), 7-22.

Crichton, M.T. (2009). Improving team effectiveness using tactical decision games. Safety Sci., 47(3), 330-336.

Crichton, M.T. and Flin, R. (2004). Identifying and training non-technical skills of nuclear emergency response teams. Ann. Nucl. Energy, 31(12), 1317-1330. http://doi.org/10.1016/j.anucene.2004.03.011. 
Crichton, M.T., Flin, R., and Rattray, W.A.R. (2000). Training Decision Makers - Tactical Decision Games. J. Contingencies Crisis Manag., 8(4), 208-217. http://doi.org/10.1111/1468-5973.00141.

Crocq, L., Huberson, S., and Vraie, B. (2009). Gérer les grandes crises sanitaires, économiques, politiques et économiques. Odile Jacob, Paris.

Csikszentmihalyi, M. (1991). Flow: The Psychology of Optimal Experience. Harper Perennial, New York.

Dautun, C. (2007). Contribution à l'étude des crises de grande ampleur: connaissance et aide à la décision pour la Sécurité Civile. $\mathrm{PhD}$ Thesis, Ecole Nationale Supérieure des Mines de Saint-Etienne.

Dautun, C. and Lacroix, B. (2013). Crise et décision : plongée au coeur des cellules de crise. Cahiers de La Sécurité, 24.

Dautun, C., Pardini, G., and Roux-dufort, C. (2011). La formation des acteurs publics à la gestion de crise : Le cas français. 11th Conference on Civil Security, 16-17 February.

Denis, H. (1993). Gérer les catastrophes, l'incertitude à apprivoiser. Les Presse de l'Université de Montréal, Montreal.

Department of Homeland Security FEMA (2005). Homeland Security Exercise and Evaluation Program, Volume $V$ : Prevention Exercises. Washington, DC.

Department of Homeland Security FEMA (2013). Homeland Security Exercise and Evaluation Program. Washington, DC.

Department of Homeland Security FEMA (2015). Training Glossary.

Direction de la Défense et de la Sécurité Civile (2005). Plan Communal de Sauvegarde: Guide pratique d'élaboration. Paris.

Edmond, P. (2011). Crise et Improvisation Organisationnelle : les leçons de quatre études de cas. PhD Thesis, University of Strasbourg.

Fréalle, N. (2018). Formation à la gestion de crise à l'échelle communale : méthode d'élaboration et de mise en oeuvre de scénarios de crise crédibles, pédagogiques et interactifs. $\mathrm{PhD}$ Thesis, University of St-Etienne.

Gaultier-Gaillard, S., Persin, M., and Vraie, B. (2012). Gestion de crise - Les exercices de simulation : de l'apprentissage à l'alerte. Afnor, Paris. 
Goebel, D.J. and Humphreys, M.A. (2014). The Relationships Among Student Learning Styles, Course Delivery Method, and Course Outcomes: A quasi-experiment investigating the case method of course delivery. Atl. Mark. J., 3(2), 4.

Goodrich, D.C. and Edwards, F.L. (2014). Improvised explosive devices. In Crisis and Emergency Management: Theory and Practice, 2nd edition, Farazmand, A (ed.). CRC Press, Boca Raton.

Goutx, D. (2014). Réaliser la gravité d'enjeux abstraits à travers une simulation : comprendre COP-RW comme un rite de passage. Négociations, 2, 17-28. doi:10.3917/neg.022.0017.

Goutx, D. (2017). Ludicité des simulations de crise, ce qui se joue au cœur d'une crise simulée. Journée de la Recherche, 16 October, Alès.

Guarnieri, F., Travadel, S., Martin, C., Portelli, A., and Afrouss, A. (2015). L'accident de Fukushima Dailchi, Le récit du directeur de la centrale. Vol. 1, L'anéantissement.

Guarnieri, F., Travadel, S., Martin, C., Portelli, A., Afrouss, A., and Eric, P. (2016). L'accident de Fukushima Dai Ichi. Presses des Mines, Paris.

Guéraud, V. (2003). Pour une ingénierie des situations actives d'apprentissage, Environnements interactifs pour l'apprentissage humain. EIAH 2003 Conference, Strasbourg, France.

Guéraud, V. (2005). Approche Auteur pour les Situations Actives d'Apprentissage: Scénarios, Suivi et Ingénierie. Thesis, Joseph Fourier University, Grenoble.

Guzzo, R. and Salas, E. (1995). Team effectiveness and decision making in organizations. Pfeiffer, San Francisco.

Heiderich, D. (2010). Plan de gestion de crise : organiser, gérer et communiquer en situation de crise. Dunod, Paris.

Heinzen, B. (1995). Crisis Management and Scenarios: the Search for an Appropriate Methodology. Ministry of Home Affairs, The Hague.

Helmreich, R.L., Foushee, H.C., Benson, R., and Russini, W. (1986). Cockpit resource management: exploring the attitude-performance linkage. Aviat. Space Environ. Med., 57, 1198-1200. 
Henriksen, K., Battles, J., Keyes, M., and Grady, M. (2008). Advances in patient safety: New directions and alternatives approaches, Vol. 2: Culture and Redesign. AHRQ Publication No. 08-0034-2. Agency for Healthcare Research and Quality, Rockville, MD.

Hotte, R. (2016). Modélisation d'environnements fonctionnels. Journée Scientifique du LICEF. pp. 89-93

Hussain, T., Feurzeig, W., Cannon-Bowers, J., Coleman, S., Koenig, A., Lee, J., Menaker, E., Moffitt, K., Pounds, K., Roberts, B., Seip, J., Souders, V., and Wainess, R. (2010). Development of game-based training systems: lessons learned in an inter-disciplinary field in the making. In Serious Game Design and Development: Technologies for Training and Learning, Cannon-Bowers, J. and Bowers, C. (eds), IGI Global, Hershey, 47-80.

Idasiak, V., Pensec, R., Olivier, N. (2006). Virtual POI: Method and tools, 15 ème congrès de maîtrise des risques et de sûreté de fonctionnement, Lille.

Joab, M., Guéraud, V., Auzende, O. (2005). Les Simulations pour la Formation. In Environnements Informatiques et Apprentissages Humains, Grandbastien, M. and Labat, J.-M. (eds), Hermès-Lavoisier, Paris.

Kanki, B.G. (2010). Communication and Crew Resource Management. In Crew Resource Management, Kanki, B.G., Helmreich, R. and Anca, J. (eds), Academic Press, Cambridge. http://doi.org/10.1016/B978-0-12374946-8.10004-4.

Kim, D.-Y., Choe, Y., and Kim, S.-A. (2015). Implementing a digital model for smart space design: Practical and pedagogic issues. Procedia - Soc. Behav. Sci., 174, 3306-3313.

Kincaid, J.P., Donovan, J., Pettitt, B. (2003). Simulation techniques for training emergency response. Int. J. Emerg. Manag., 1(3), 238-246.

King, H.B., Battles, J.B., Baker, D.P., Alonso, A., Salas, E., Webster, J., and Grady, M.L. (2008). TeamSTEPPS: Team strategies and tools to enhance performance and patient safety. In Advances in Patient Safety: New Directions and Alternative Approaches (Vol. 3: Performance and Tools), Henriksen, K., Battles, J., Keyes, M. and Grady, M. (eds), Agency for Healthcare Research and Quality, Rockville.

Klein, G. (1997). The recognition-primed decision (RPD) model: looking back, looking forward. In Naturalistic Decision Making, Zsambok, C. and Klein, G. (eds), Lawrence Erlbaum Associates, Inc., Hillsdale. 
Kontogiannis, T. and Kossiavelou, Z. (1999). Stress and team performance: Principles and challenges for intelligent decision aids. Safety Sci., 33(3), 103-128. http://doi.org/10.1016/S0925-7535(99)00027-2.

Kouabenan, D.R., Cadet, D., and Sastre, M.T.M. (2006). Psychologie du risque : identifier, évaluer, prévenir. De Boeck, Brussels.

Kovordanyi, R., Schreiner, R., Jenvald, J., Eriksson, H., and Rankin, A. (2012). Real-time Support for Exercise Managers' Situation Assessment and Decision Making, ISCRAM12, April, Vancouver, pp. 1-5, 2012.

Kowalski-Trakofler, K. M., Vaught, C., and Scharf, T. (2003). Judgment and decision making under stress: an overview for emergency managers. Int. J. Emerg. Manag., 1(3), 278. http://doi.org/10.1504/IJEM.2003.003297.

Labat, J.M., Pernin, J.P., Guéraud, V. (2006). Contrôle de l'activité de l'apprenant: suivi, guidage pédagogique et scénarios d'apprentissage. In Environnements informatiques pour l'apprentissage humain, Grandbastien, M. and Labat, J.-M. (eds), Hermes-Science Lavoisier, Paris.

Lachtar, D. (2012). Contribution des systèmes multi-agent à l'analyse de la performance organisationnelle d'une cellule de crise communale. $\mathrm{PhD}$ Thesis, Ecole Nationale Supérieure des Mines de Paris, Paris.

Lagadec, P. (1995), Cellule de crise, les conditions d'une conduite efficace. Les éditions d'Organisation, Paris.

Lagadec, P. (2010). La Force de Réflexion Rapide - Aide au pilotage des crises. Préventique Sécurité, 112 pp. 31-35, 2010.

Lagadec, P. (2012). Du risque majeur aux mégachocs. Préventique, Bordeaux.

Lagadec, P. (2015). Le continent des imprévus - Journal de bord des temps chaotiques. Ed. Manitoba/Les Belles Lettres. Paris.

Lagadec, P. and Guilhou, X. (2002a). La fin du risque zéro. Eyrolles, Paris.

Lagadec, P. and Guilhou, X. (2002b). Les conditions de survenue des crises graves. In Conditions et mécanismes de production des défaillances, accidents et crises, Amalberti, R., Fuchs, C. and Gilbert, C. (eds), Publications de la MSH-ALPES, Grenoble, pp. 157-210.

Lapierre, D., (2016). Méthode EVADE: Une approche intégrée pour l'EValuation et l'Aide au DEbriefing. PhD Thesis, Université de NîmesIMT Mines Alès. 
Lee, D.A., Ford, N.P., Freeland, R.L., Hough, J.A., Bridge, G.G. (2006). Guidelines for Transportation Emergency Training Exercises. McCormick Taylor Firm.

Lhuillier, B. (2011). Concevoir un seriousgame pour un dispositif de formation. FYP Editions, Paris.

Limousin, P. (2017). Contribution à la scénarisation pédagogique d'exercices de crise, PhD Thesis, Ecole Nationale Supérieure des Mines de Saint-Etienne.

Llory, M. (1996). Accidents industriels : le coût du silence. Opérateurs privés de parole et cadres introuvables. L'Harmattan, Paris.

Lourdeaux, D. (2001). Réalité Virtuelle et Formation: Conception d'Environnements Virtuels Pédagogiques, PhD Thesis, Ecole des Mines de Paris, Paris.

Lukosch, H., van Ruijven, T., Verbraeck, A. (2012). The participatory design of a simulation training game. Proceedings of the 2012 Winter Simulation Conference (WSC), pp. 1-11. doi:10.1109/WSC.2012.6465218.

MAEE (2017). La diplomatie de l'Urgence, Centre de crise, Ministère des Affaires étrangères et du Développement international. Available: https://www.diplomatie.gouv.fr/IMG/pdf/cdes_2017-web_cle8b741e1.pdf

Maisonneuve, D. (2010). Les relations publiques dans une société en mouvance, 4 th edition. PUQ, Sainte-Foy.

Marks, M.A., Mathieu, J.E. and Zaccaro, S.J. (2001). A temporally based framework and taxonomy of team processes. Acad. Manag. Rev., 26(3), 356-376. http://doi.org/10.5465/AMR.2001.4845785.

Martin, G. (2014). La place des communautés d'utilisateurs dans les dispositifs de gestion de crise. Les médias sociaux en gestion d'urgence (M.S.GU.), ENSOSP.

Mellet d'Huart, D. (2001). La réalité virtuelle: un média pour apprendre, Cinquième Coloque Hypermédias et Apprentissage, Grenoble, France.

Mendonca, D., Beroggi, G.E.G., Gent, D. and Wallace, W.A. (2006). Designing gaming simulations for the assessment of group decision support systems in emergency response. Safety Sci., 44(6), 523. 
Morin, M., Jenvald, J., Thorstensson, M. (2004). Training first responders for public safety using modeling, simulation, and visualization, SIMSafe, Karlskoga.

Moulin, M.-C. (2014). La gestion des crises "hors cadre”, "L'inconcevable n'est pas impensable!’. L'Harmattan, Paris.

Nissen, E. (2009). Formation hybride vs. présentielle en langues : effets sur la perception des apprenants liés au mode de formation et à l'encadrement pédagogique. Recherches en didactique des langues et des cultures. Les Cahiers de l'Acedle, 6 (6-1), 197-220.

Noori, N.S., Wang, Y., Comes, T. (2017). Behind the Scenes of Scenario-Based Training: Understanding Scenario Design and Requirements in High-Risk and Uncertain Environments. Proceedings of the 14th ISRAM Conference, Albi, France.

O’Connor, P. (2007). Naval Aviation Schools Command Pensacola, FL.

O'Connor, P. and O'Dea, A. (2002). The U.S. Navy's aviation safety program: A critical review. Int. J Appl. Aviation Stud., 7(2): 312-328.

Orasanu, J.M. (2010). Flight crew decision-making. In Crew Resource Management, Kanki, B., Helmreich, R. and Anca, J. (eds), Academic Press, Cambridge. http://doi.org/10.1016/B978-0-12-374946-8.10005-6

Pastré, P. (2005). Apprendre par la résolution de problèmes: le rôle de la simulation. In Apprendre par la simulation - De l'analyse du travail aux apprentissages professionnels, Pastré, P. (ed.), Toulouse, France, 2005.

Pastré, P., Vergnaud, G. (2011). L’ingénierie didactique professionnelle. In Traité des sciences et des techniques de la Formation, Carré, P. and Gaspar, P. (eds), Dunod, Paris.

Pearson, C.M., Kovoor-Misra, S., Clair, I.I., Mitroff, J.A. (1997). Managing the Unthinkable. Organizational Dynamics, 26(2), 51-64.

Pernin, J.-P. (1996). M.A.R.S. Un modèle opérationnel de conception de simulations pédagogiques, $\mathrm{PhD}$ Thesis, Université Joseph Fourier Grenoble I, Grenoble.

Power, D., Henn, P., Power, T., and McAdoo, J. (2013). An evaluation of high fidelity simulation training for paramedics in Ireland. Int. Paramed. Pract., 2(1), 11-18. 
Quarantelli, E.L. (1988). Disaster crisis management: a summary of research findings. J. Manag. Stud., 25(4), 373-385. http://doi.org/DOI: 10.1111/j.1467-6486.1988.tb00043.x.

Querrec, R. (2002). Les systèmes multi-agents pour les environnements virtuels de formation, $\mathrm{PhD}$ Thesis, Université de Bretagne Occidentale.

Quinton, A. (2007). Besoins, finalités, programmes, objectifs opérationnel.

Rehmann, A. (1995). A Handbook of Flight Simulation Fidelity Requirements for Human Factors Research, Federal Aviation Administration Centre.

Renaudin, H. and Altemaire, A. (2007). Gestion de crise mode d'emploi, Principes et outils pour s'organiser et manager les crises. Editions Liaisons, Paris.

Renger, R., Wakelee, J., Bradshaw, J., and Hites, L. (2009). Steps in writing an effective master scenario events list. J. Emerg. Manag., 7(6), 51-60.

Rohrer, M.W. (2000). Seeing in believing: the importance of visualization in manufacturing simulation. The 2000 Winter Simulation Conference, 10-13 December 2000, Orlando, FL, pp. 1211-1216.

Roux-Dufort, C. and Ramboatiana, S. (2006). Gestion de crise : les managers possédés par leurs démons. Magazine de la communication de crise et sensible, Observatoire International des Crises.

Salas, E. and Cannon-Bowers, J.A. (2001). The science of training : A decade of progress. Ann. Rev. Psychol., 52(1), 471-499.

Salas, E., Dickinson, T.L., Converse, S.A., and Tannenbaum, S.I. (1992). Toward an understanding of team performance and training. In Teams: their training and performance, Swezey, R.W. and Salas, E. (eds). Norwood, pp. 3-29.

Sauvagnargues, S., Poppi, J.-C. (2012). Cartographies opérationnelles. In Incendies de forêts: défis et perspectives, Sauvagnargues, S. (ed.). Hermes-Lavoisier, pp. 265-302.

Sayegh, L., Anthony, W.P., and Perrewé, P.L. (2004). Managerial decision-making under crisis: The role of emotion in an intuitive decision process. Hum. Resour. Manag. Rev., 14(2), 179-199. http://doi.org/ 10.1016/j.hrmr.2004.05.002

Schank, R.C. (1992). Goal-Based Scenarios, Technical Report no. 36, pp. 61-21. 
Schurr, N., Patil, P., Pighin, F., Tambe, M. (2006). Using multiagent teams to improve the training of incident commanders. In 5th International Joint Conference on Autonomous Agents and Multi Agent Systems (AAMAS) Industry Track, ACM, New York, NY.

Seppänen, H., Mäkelä, J., Luokkala, P., and Virrantaus, K. (2013). Developing shared situational awareness for emergency management. Safety Sci., 55, 1-9. http://doi.org/10.1016/j.ssci.2012.12.009.

Shanahan, C., Best, C., Finch, M., and Sutton, C. (2007). Measurement of the behavioural, cognitive, and motivational factors underlying team performance. Report, Australian Department of Defence, Defence Science and Technology Organisation (DSTO).

Shapiro, M.J., Gardner, R., Godwin, S.A., Jay, G.D., Lindquist, D.G., Salisbury, M.L., and Salas, E. (2008). Defining team performance for simulation-based training: Methodology, metrics, and opportunities for emergency medicine. Acad. Emerg. Med., 15(11), 1088-1097. http://doi.org/10.1111/j.1553-2712.2008.00251.x.

Shrivastava, P., Mitroff, I., and Alpaslan, C.M. (2012). Imagining an education in crisis management. J. Manag. Edu., 37(1), 6-20. doi:10.1177/1052562912455418.

Smith, W. and Dowell, J. (2000). A case study of co-ordinative decision making in disaster management. Ergonomics, 48(8), 1153-1166.

Solucom Management \& IT Consulting (2014). QSE : qualité et gouvernance des systèmes d'information Module $\mathrm{n}^{\circ} 4$ : la gestion de crise. INSA Toulouse, 2014. [Online]. Available: http://moodle.insa-toulouse.fr/ pluginfile.php/44681/mod_resource/content/1/QSE 2014 - Solucom - 4. La gestion de crise 1.0.pdf.

Stern, E.K. (2014). Designing Crisis Management Training and Exercises for Strategic Leaders. Försvarshögskolan, Stockholm.

Suchet, R. (2015), La gestion du nucléaire en crise - Une étude à travers les représentations des gestionnaires de crise. PhD Thesis, University of Montpellier 1.

Sundstrom, E., de Meuse, K.P., and Futrell, D. (1990). Work teams: Applications and effectiveness. Am. Psychol., 45(2), 120-133. http:// doi.org/10.1037/0003-066X.45.2.120. 
Tena-Chollet, F. (2012). Elaboration d'un environnement semi-virtuel de formation à la gestion stratégique de crise, basé sur la simulation multi-agents. PhD Thesis, École Nationale Supérieure des Mines de Saint-Etienne.

Tissington, P. and Flin, R. (2005). Assessing risk in dynamic situations: lessons from fire service operations. Risk Manag., 7(4), 43-51.

Van Vliet, A.J. and Van Amelsfoort, D. (2008). Multinational military teams. Multinational Military Operations and Intercultural Factors, NATO OTAN.

Vaughan, A. (1996). The Challenger Launch Decision: Risky Technology, Culture, and Deviance at NASA (University). Chicago and London.

Vraie, B., Huberson, S., and Crocq, L. (2010). Cellule de crise et dynamique de groupe. Magazine de La Communication de Crise et Sensible, 4-9.

Weick, K.E. (1995). Sensemaking in Organizations. Sage, Thousand Oaks.

Weil, S.A., Hussain, T.S., Diedrich, F.J., Ferguson, W. and MacMillan, J. (2004). Assessing distributed team performance in DARWARS training: Challenges and methods. Proceedings of the Interservice/Industry Training, Simulation, and Education Conference, Orlando, FL, 2004.

Wybo, J.L. (2009). Le retour d'expérience. Un processus d'acquisition de connaissances et d'apprentissage. In La Gestion de crise: le maillon humain au sein de l'organisation, Specht, M. and Planchette, G. (eds). Economica, Paris. 
1 